\title{
Point Sampling to Stratify Biomass Variability in Sagebrush Steppe Vegetation
}

\author{
Patrick E. Clark, ${ }^{1}$ Stuart P. Hardegree, ${ }^{2}$ Corey A. Moffet, ${ }^{3}$ and Fredrick B. Pierson ${ }^{4}$ \\ Authors are ${ }^{1}$ Range Scientist, ${ }^{2}$ Plant Physiologist, and ${ }^{4}$ Supervisory Research Hydrologist, USDA Agricultural Research Service, \\ Northwest Watershed Research Center, Boise, ID 83712, USA; and ${ }^{3}$ Range Scientist, USDA Agricultural Research Service, US Sheep Experiment Station, \\ Dubois, ID 83423, USA.
}

\begin{abstract}
Cover and yield are two of the most commonly monitored plant attributes in rangeland vegetation surveys. These variables are usually highly correlated and many previous authors have suggested point-intercept estimates of plant cover could be used as a surrogate for more expensive and destructive methods of estimating plant biomass. When measurement variables are highly correlated, double sampling can be used to prestratify variability in the measurement that is more difficult or costly to obtain, thus improving sampling efficiency. The objective of this study was to examine the cost effectiveness of using point-intercept data to prestratify variability in subsequent clipped-biomass sampling on a sagebrush-bunchgrass rangeland site in southern Idaho. Point-intercept and biomass data were obtained for shrub, grass, and forb vegetation in $901-\mathrm{m}^{2}$ plots. These data were used to develop a synthetic population of 10000 simulated plots for conducting sensitivity analysis on alternative doublesampling scenarios. Monte Carlo simulation techniques were used to determine the effect of sampling design on cost and variability of biomass estimates as a function of point-intercept sample size $(i)$, number of point-intercept sample strata $(s)$, and number of biomass samples per stratum $(m)$. Minimization of variability in biomass estimates were always obtained from double-sampling scenarios in which a single median biomass estimate was obtained for a given stratum in the point-intercept data. Double-sampling strategies in which half of the point-intercept plots were also measured for biomass yielded a cost savings of $39 \%$ with a reduction in biomass-sample precision of $18 \% \pm 4 \mathrm{SD}$. The relative loss of precision in biomass estimates $(62 \% \pm 12 \mathrm{SD})$ became equal to the relative cost savings of double sampling for scenarios in which the ratio of point-intercept/ biomass samples exceeded a value of five.
\end{abstract}

\section{Resumen}

La cobertura y rendimiento son dos de los atributos de vegetación que son monitoreados más comúnmente en los estudios de vegetación en los pastizales. Estas variables son por lo general altamente correlacionadas y muchos autores anteriores han sugerido que estimaciones de punto-intercepción de la cobertura vegetal podría ser usado como una alternativa a métodos más caros y destructivos de estimación de biomasa vegetal. Cuando las variables de medición son altamente correlacionadas, un muestreo doble puede ser usado para pre-estratificar la variabilidad en la medición que es más difícil y costosa de obtener, mejorando así, la eficiencia del muestreo. El objetivo de este estudio fue examinar la efectividad del costo de usar datos de punto de intercepción para pre-estratificar la variabilidad de un muestreo subsecuente de corte de biomasa en un sitio estepa de triguillo crestado en el sur de Idaho. El punto de intercepción y los datos de biomasa fueron obtenidos de la vegetación de arbustos y hierbas en 90 parcelas de $1 \mathrm{~m}^{2}$. Estos datos fueron utilizados para desarrollar una población sintética de 10000 parcelas simuladas para llevar a cabo un análisis de sensibilidad en alternativa a los escenarios de muestreos dobles. Las técnicas de la simulación de Monte Carlo fueron utilizadas para determinar el efecto del diseño de muestreo en el costo y la variabilidad de la estimación de biomasa como una función del tamaño de la muestra del punto de intercepción (i), el número de muestra de estrato del punto de intercepción $(s)$, y el número de muestras de biomasa por estratos $(m)$. La minimización en la variabilidad de la estimación de la biomasa fue obtenida siempre de los escenarios de muestreo doble en el cual una estimación mediana simple de biomasa fue obtenida de un estrato dado en los datos de punto de intercepción. Las estrategias de muestreo doble en el que la mitad de las parcelas de punto de intercepción fueron medidas también para la biomasa produjeron un ahorro en el costo de $39 \%$ con una reducción en la precisión de la muestra de biomasa de $18 \% \pm 4 \mathrm{SD}$. La pérdida relativa de la precisión en la biomasa estimada $(62 \% \pm 12 \mathrm{SD})$ fue similar al ahorro del costo relativo del muestreo doble de los escenarios en el cual la proporción de muestras de punto de intercepción/biomasa exceden un valor de 5 .

Key Words: forbs, grasses, nondestructive sampling, relative cost, shrubs

\section{INTRODUCTION}

Species composition, cover, and yield are the most commonly measured attributes for assessing rangeland vegetation (Cain and de Oliveira Castro 1971; Stoddart et al. 1975; Greig-Smith

Correspondence: Patrick E. Clark, USDA-ARS, Northwest Watershed Research Center, 800 Park Boulevard, Suite 105, Boise, ID 83712-7716, USA. Email: pclark@nwrc.ars.usda.gov

Manuscript received 18 December 2007; manuscript accepted 3 July 2008.
1983). Point-intercept sampling has been used extensively to estimate botanical composition and basal and foliar cover but corresponding yield estimates are generally obtained by drying and weighing clipped plant material (Bonham 1987). Many previous studies have noted well-defined relationships between point-intercept and yield measurements (Hughes 1962; Branson et al. 1966; Vogel and Van Dyne 1966; Poissonet et al. 1973; Ganskopp and Miller 1986; Aase 1987; Heitschmidt and Dowhower 1991), and several authors have suggested less- 
expensive point data could be used as a surrogate for more expensive and destructive biomass estimates (Wilm 1944; Reppert et al. 1962; Blankenship and Smith 1966; Reese et al. 1980; Ahmed et al. 1983; Glatzle et al. 1993). Most studies that include regressible point and yield data, however, do not quantify the relationship between variables, nor do they suggest how these data could be used to design an experimental protocol for optimizing sample estimates for a given cost (Hyder and Sneva 1956; Hazell 1965; Branson et al. 1966; Conant and Risser 1974; Wight et al. 1978; Pitt and Heady 1979; Papanastasis 1985; Schacht and Stubbendieck 1985; Tanner et al. 1988; Owens et al. 1991; Glatzle et al. 1993; Smith et al. 1994).

Kaur et al. (1998) reviewed Ranked Set Sampling (RSS), a double-sampling technique in which an inexpensive measurement variable can be used to stratify variability to increase sampling efficiency of a more expensive variable. Tsutsumi et al. (2007) evaluated optimal sample-size requirements for RSS sampling of herbaceous biomass, but Patil and Taillie (1993) have suggested regression techniques are a more efficient basis for stratification if correlation between variables is higher than about 0.85. Wilm (1944) and Jonasson (1988) used regression data to subsequently estimate weight from point samples, but the accuracy and cost of these estimates was fixed by the initial random-sampling procedure. Ahmed and Bonham (1982) and Ahmed et al. (1983) describe optimization techniques for obtaining regression data through double sampling but do not use variability estimates to stratify sampling of the more costly parameter. Uresk et al. (1977) and Pitt and Schwab (1990), however, have demonstrated double-sampling cost efficiency by using shrub-volume measurements to stratify variability in subsequent estimates of plant biomass.

The objectives of our study were to evaluate the relationship between point-intercept and biomass variables for a mountain big sagebrush (Artemisia tridentata Nutt. subsp. vaseyana [Rydb.] Beetle) plant community; develop double-sampling procedures to stratify variability to make subsequent biomass sampling more efficient; and propose a general strategy for reducing total sample cost for estimating cover and biomass.

\section{MATERIALS AND METHODS}

\section{Study Area}

This study was conducted in June 2002 at the Breaks study area (81 ha) within the Reynolds Creek Experimental Watershed (lat $43^{\circ} 6^{\prime} 29^{\prime \prime} \mathrm{N}$, long $116^{\circ} 46^{\prime} 37^{\prime \prime} \mathrm{W}$ ), located $80 \mathrm{~km}$ south of Boise in southwestern Idaho. Mean annual precipitation at the site is $471 \mathrm{~mm}$ with $34 \%$ occurring as snow (Hanson 2001). The growing season is about $120 \mathrm{~d}$, but frost can occur during any month of the year. Long-term (1967 to 1996) mean daily maximum and minimum and mean air temperatures at nearby Low Sheep Creek weather station are $12.1^{\circ} \mathrm{C}, 3.7^{\circ} \mathrm{C}$, and $7.9^{\circ} \mathrm{C}$, respectively (Hanson et al. 2001).

The study area was on an east-facing slope ranging from $1547 \mathrm{~m}$ to $1761 \mathrm{~m}$ in elevation. Soils were a complex of Takeuchi (coarse, loamy, mixed, frigid Typic Haploxerolls) and Kanlee (fine, loamy, mixed, frigid Typic Argixerolls). Three plant communities dominated the study area: 1) a mountain big sagebrush-mountain snowberry (Symphoricar- pos oreophilus Gray) community, which also included western juniper (Juniperus occidentalis Hook.), yellow rabbitbrush (Chrysothamnus viscidiflorus [Hook.] Nutt.), bluebunch wheatgrass (Pseudoroegneria spicata [Pursh] Love), Sandberg bluegrass (Poa secunda J. Presl.), bottlebrush squirreltail (Elymus elymoides [Raf.] Swezey), Idaho fescue (Festuca idahoensis Elmer), basin wildrye (Leymus cinereus [Scribn. \& Merr.] A. Love), mountain brome (Bromus marginatus Nees ex Steud.), tapertip hawksbeard (Crepis acuminata Nutt.), and western aster (Symphyotrichum ascendens [Lindl.] Nesom); 2) an antelope bitterbrush (Purshia tridentata [Pursh] DC)mountain big sagebrush community, which also included western juniper, native bunchgrasses, and biscuitroots (Lomatium spp. Raf.); and 3) a native bunchgrass community dominated by bluebunch wheatgrass, Sandberg bluegrass, bottlebrush squirreltail, Idaho fescue, and needlegrasses (Achnatherum spp. Beauv.).

\section{Field Sampling}

A vegetation map was developed by classifying an airborne hyperspectral image of the study area, acquired in September 2001. Within each of the three plant communities delineated on the map, 30 random plot locations were identified and located in the field using a global positioning system unit. Plots placed in the wrong plant community because of map error were moved to a new random location within the nearest stand of the appropriate community. A square, $1-\mathrm{m}^{2}$ sampling quadrat was placed at each plot location and anchored with steel staples so that the plot boundaries were oriented along the cardinal directions. Reference marks were etched at $16.7-\mathrm{cm}$ intervals along the edges of each quadrat to identify five sampling stations for a 20-pin-point frame. Point-intercept sampling was accomplished by slowly pushing each pin vertically through the vegetation canopy and classifying and recording each pin-point contact or intercept. The final point-intercept with the soil surface, or with material in direct contact with the soil, was classified and recorded as a basal intercept. Point intercepts with live plant material were recorded to functional group, and photosynthetically active (i.e., all green leaves and stems combined) tissue was differentiated from nonphotosynthetically active tissue. Intercepts with nonliving plant materials were recorded to functional group, and standing/attached material was differentiated from down/unattached material (Table 1). This sampling process was repeated for all five sampling stations per plot.

Biomass sampling within each plot was conducted within $72 \mathrm{~h}$ of point sampling. All vegetation material, including animal dung, located within the vertical projection of the sampling quadrat were harvested to ground level, sorted according to functional group and live or dead status, and stored in paper bags. The 10 categories sampled for biomass are listed in Table 1. Biomass samples were oven-dried at $50^{\circ} \mathrm{C}$ until a consistent weight was reached, and that weight was recorded.

\section{Synthetic-Population Generation and Analysis}

Regression analysis was used to define the relationship between biomass $\left(Y ; \mathrm{g} \cdot \mathrm{m}^{-2}\right)$ and point-intercept frequency $(X$; intercepts $\cdot \mathrm{m}^{-2}$ ) for each functional group/status category (Tables 1 and 2). Quadratic and linear regression coefficients were 
Table 1. The mean and standard deviation of biomass and point-intercept values for 10 functional group and live-dead status categories of vegetation material sampled from $901-\mathrm{m}^{2}$ plots, except in shrub-green, shrub-wood, and down-wood categories where 60 plots were used, during peak standing crop (June) in 2002 at the Breaks study area within the Reynolds Creek Experimental Watershed near Murphy in southwestern Idaho. Also shown are mean and standard deviation of biomass and point-intercept values for the shrub-green, forb, and grass categories from 10000 synthetic plots, derived using Monte Carlo techniques.

\begin{tabular}{|c|c|c|c|c|c|c|c|c|}
\hline \multirow[b]{3}{*}{$\begin{array}{l}\text { Functional group/ } \\
\text { category }{ }^{1}\end{array}$} & \multicolumn{4}{|c|}{ Sampled } & \multicolumn{4}{|c|}{ Synthetic $(n=10000)$} \\
\hline & \multicolumn{2}{|c|}{ Biomass } & \multicolumn{2}{|c|}{ Point intercepts } & \multicolumn{2}{|c|}{ Biomass } & \multicolumn{2}{|c|}{ Point intercepts } \\
\hline & $\begin{array}{c}\text { Mean } \\
\left(\mathrm{g} \cdot \mathrm{m}^{-2}\right)\end{array}$ & $\begin{array}{c}S D \\
\left(\mathrm{~g} \cdot \mathrm{m}^{-2}\right)\end{array}$ & $\begin{array}{c}\text { Mean } \\
\text { (intercepts } \cdot \mathrm{m}^{-2} \text { ) }\end{array}$ & $\begin{array}{c}\mathrm{SD} \\
\left(\text { intercepts } \cdot \mathrm{m}^{-2} \text { ) }\right.\end{array}$ & $\begin{array}{c}\text { Mean } \\
\left(\mathrm{g} \cdot \mathrm{m}^{-2}\right)\end{array}$ & $\begin{array}{c}S D \\
\left(\mathrm{~g} \cdot \mathrm{m}^{-2}\right)\end{array}$ & $\begin{array}{c}\text { Mean } \\
\left(\text { intercepts } \cdot \mathrm{m}^{-2} \text { ) }\right.\end{array}$ & $\begin{array}{c}\mathrm{SD} \\
\left(\text { intercepts } \cdot \mathrm{m}^{-2} \text { ) }\right.\end{array}$ \\
\hline Tree-green & 2.3 & 18.9 & 0 & 0 & & & & \\
\hline Shrub-green ${ }^{2}$ & 114.5 & 91.5 & 53.7 & 46.0 & 136.1 & 81.9 & 63.2 & 38.1 \\
\hline Forb & 56.6 & 52.6 & 29.1 & 28.3 & 68.2 & 46.3 & 35.9 & 22.8 \\
\hline Grass & 58.6 & 63.4 & 27.1 & 21.1 & 63.8 & 59.4 & 30.3 & 18.0 \\
\hline Moss & 30.1 & 90.9 & 4.3 & 8.2 & & & & \\
\hline Tree-wood & 0.4 & 4.1 & 0 & 0 & & & & \\
\hline Shrub-wood & 1141.8 & 1207.8 & 34.8 & 31.3 & & & & \\
\hline Down-wood & 248.2 & 295.4 & 4.5 & 4.5 & & & & \\
\hline Litter & 650.1 & 522.7 & 62.7 & 36.6 & & & & \\
\hline Dung & 47.3 & 123.9 & 2.2 & 5.4 & & & & \\
\hline
\end{tabular}

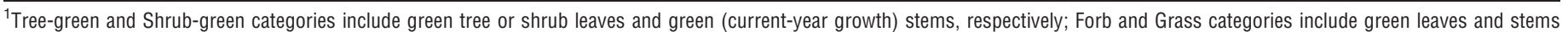

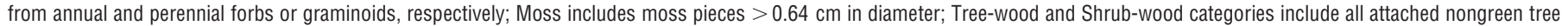

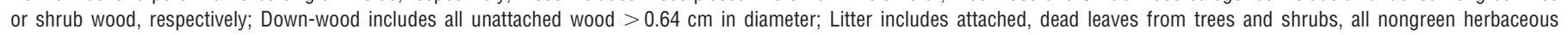
material, and all other down vegetation material and dung $<0.64 \mathrm{~cm}$ in diameter; and Dung includes all dung pieces $>0.64 \mathrm{~cm}$ in diameter.

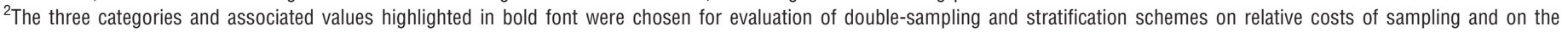
accuracy of biomass estimation using Monte Carlo simulation techniques.

retained if significant $(P \leq 0.05)$. Shrub-green (shrub), forb, and grass categories were used for subsequent analysis of doublesampling efficiency because they were of greatest interest for leaf area, cover, and biomass monitoring applications (Fig. 1). All 90 plots from the three mapped plant community classes were used for analysis of grass and forb data. Shrub data were only used from the 60 plots within the two shrub cover-type classes because only two plots in the bunchgrass community contained any shrub material. Regression model residuals from the shrub, forb, and grass categories were subjected to a Breusch-Pagan test to determine whether biomass variance was constant over the range of point-intercept counts observed (Breusch and Pagan 1979).

Regression parameters were used to generate a synthetic sample population of 10000 paired biomass/point-intercept plots for each vegetation category. Creation of a synthetic population was begun by randomly generating point-intercept values from a normal distribution with $X \sim N\left(\bar{X}_{0}, s^{2}\right)$ where $\bar{X}_{0}$ is the mean point-intercept value of the original $N$ plots, and $s^{2}$ is the point-intercept sample variance. A synthetic biomass value, $Y_{i}$, was estimated for each synthetic point-intercept value, $X_{i}$, from the following equations:

$$
Y_{i}=b_{0}+b_{1} X_{i}+b_{2} X_{i}^{2}+\varepsilon_{i}
$$

and

$$
\varepsilon_{i}=N\left(0, c+d X_{i}\right)
$$

where $b_{i}$ are the fitted regression parameters for the pointbiomass relationship; and $c$ and $d$ are regression parameters that characterize the relationship between biomass error

Table 2. Regression model $\left(b_{i}\right)$ and heterogeneous error rate parameters ( $c$ and $d$ ) from equations 1 and 2 , respectively, used to derive the synthetic data set of 10000 paired biomass $(Y)$ and point-intercept $(X)$ values for the Shrub-green, Forb, and Grass functional group/status categories using Monte Carlo simulations. Also included are regression model parameters and coefficient of determination (adjusted) values for

\begin{tabular}{|c|c|c|c|c|c|c|c|}
\hline Funtional $^{1}$ group & $n$ & $b_{0}$ & $b_{1}$ & $b_{2}$ & Adjusted $R^{2}$ & $c$ & $d$ \\
\hline Shrub-green & 60 & - & 2.757 & -0.007 & 0.891 & 566.11 & 31.35 \\
\hline Forb & 90 & 6.967 & 1.706 & - & 0.843 & - & 17.96 \\
\hline Moss & 90 & - & 9.390 & - & 0.528 & & \\
\hline Shrub-wood & 60 & - & 30.691 & - & 0.745 & & \\
\hline Down-wood & 60 & - & 73.154 & -2.002 & 0.700 & & \\
\hline
\end{tabular}
relationships between biomass $(Y)$ and point intercept $(X)$ from five other functional group/status categories.

${ }^{1}$ If the term was not included in the model, it is indicated with a - Relationships for Tree-green and Tree-wood were not fitted because of insufficient sample size. 

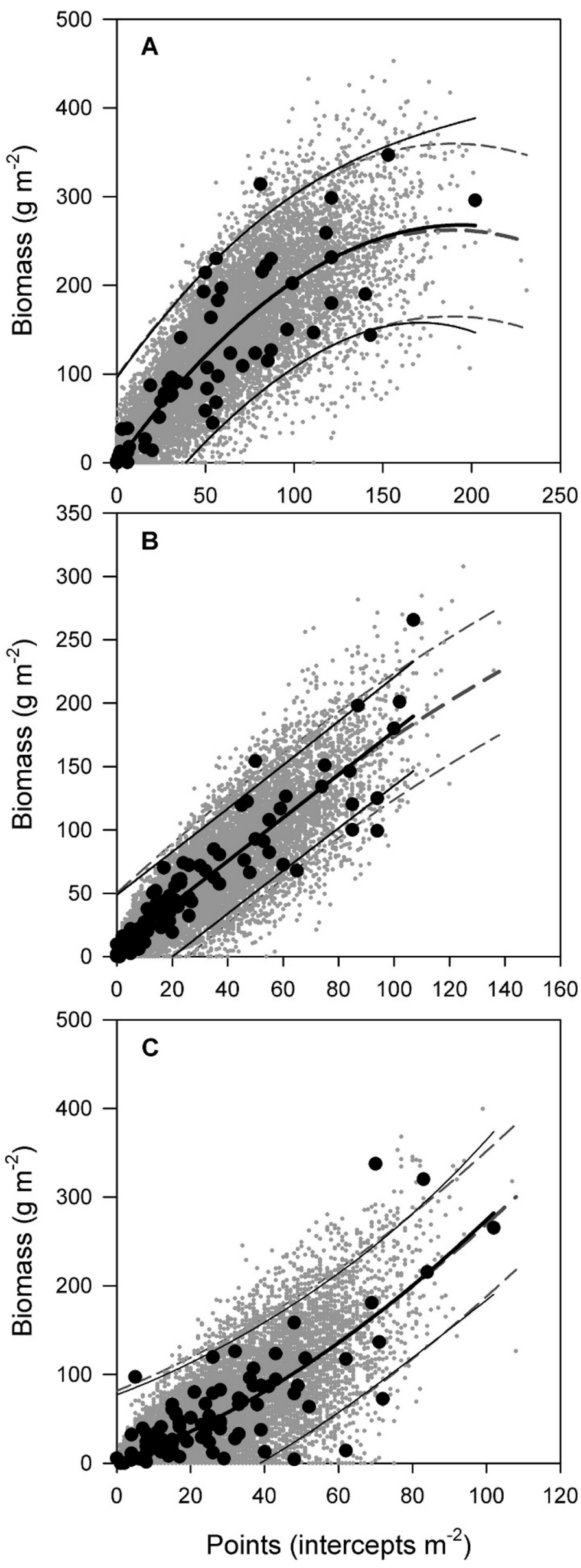

rate and point-intercept value for the accepted regression model when the Breusch-Pagan test was significant (Table 2). The $c$ and $d$ parameters are the intercept and slope, respectively, from a regression of the squared residuals on point-intercept count.

The relationship between sample size $\left(5-901-\mathrm{m}^{2}\right.$ plots $)$ and $95 \%$ prediction-interval width for mean point-intercept frequency and for mean biomass of shrub, grass, and forb categories was estimated for the synthetic population from the following equation:

$$
n=t^{2} s^{2} /(k \bar{X})^{2}
$$

where $n$ is sample size, $t$ is from the $t$ distribution with an $\alpha$ level of $0.05(\mathrm{df}=n \overline{\mathrm{X}}-1), s$ is the standard deviation, $\bar{X}$ is the mean parameter estimate, and $k$ is one-half of the $95 \%$ prediction-interval width of the mean (Bonham 1989).

Monte Carlo simulation techniques were used to evaluate the variability in total biomass estimate as a function of doublesampling strategy. Sample-size effects on prediction-interval width for both point-intercept frequency and biomass were based on 5000 iterations of random sampling of the synthetic population for all sample sizes between 5 and 90 (1- $\mathrm{m}^{2}$ plots). Double-sampling scenarios for biomass estimation were evaluated based on 5000 sampling iterations that varied in total number of plots sampled for point-intercept frequency $(i=5$ to 90); number of strata identified within the point-intercept data from which biomass samples were also taken ( $s=1$ to $i$ ); and number of random biomass samples obtained per pointintercept stratum $\left(m=1\right.$ to $\left.i^{-1}\right)$. Point-intercept data were stratified based on equal frequencies of observed pointintercept values, thus yielding strata of unequal widths. One additional sampling scheme was evaluated in which only the median point-intercept plot in each stratum was sampled for biomass. Biomass estimates from Monte Carlo simulation were evaluated for variability. Relative variability of different sampling schemes was characterized by the width of the $95 \%$ prediction interval for the mean biomass.

\section{Sampling-Cost Estimation}

Personnel costs associated with point-frame and biomass sampling were estimated in 2003 for a set of 30 quadrats

$\leftarrow$

Figure 1. Scatter-plot (large black dots) illustrating the relationships between point-intercept values, where all pin-point contacts were tallied, and oven-dried, aboveground biomass samples from three functional groups: A, Shrub (photosynthetic material only), B, Forb, and C, Grass (graminoids), collected from randomly located, $1-\mathrm{m}^{2}$ plots on a mountain big sagebrush-antelope bitterbrush rangeland in Reynolds Creek Experimental Watershed in southwestern Idaho. Also shown is a scatter-plot (small gray dots) representing point-intercept to biomass relationships in a synthetic population of 10000 data values obtained using Monte Carlo simulation techniques parameterized with BreuschPagan's test parameters derived from the field data described above. Line plots illustrate the fitted regression model (thick line) and 95\% prediction interval (thin, line pair) for the field data (black solid lines) and synthetic data (gray dashed lines). 
located about $3.5 \mathrm{~km}$ north of the Breaks study area in a site having similar elevation, aspect, soil, and plant community and cover attributes to that of the study area. Ten randomly located quadrats within each plant community were sampled using the same procedures described for the Breaks area, and time required for setting up equipment, labeling bags, pointsampling, harvesting, sorting, drying, and weighing samples was recorded for each respective sampling technique. An oven capable of accommodating approximately 30 sample bags was used to dry the samples to a constant weight. A nonparametric, Wilcoxon signed-rank test was used to test for differences in cost/time required for biomass and point-sampling (SAS 2003). Regression models were developed to quantify the relationships between point-sampling and biomass sampling times; between point-sampling and biomass-sampling times relative to total plot biomass; and between point-biomass cost ratio and total biomass. All differences reported in this article were significant at $P<0.05$, unless stated otherwise.

\section{RESULTS}

The relationship between point-intercept frequency and biomass was determined to be linear for forbs but significantly nonlinear for shrub and grass categories (Fig. 1; Table 2). The Breusch-Pagan test indicated significant heterogeneity of error variance for these three vegetation categories, and the biomass error rate was modeled as a linear function of point-intercept count (Table 2). The synthetic data were generated randomly from a normal distribution that yielded some negative simulated values. Only sample pairs with point-intercept and biomass values $>0$ were included in the synthetic population, which therefore had greater mean biomass and point-intercept frequencies than the original measured data (Table 1). Five sampling categories not used in the Monte-Carlo analysis also exhibited well-defined relationships between point-intercept frequency and biomass (Table 2). Tree-Green and Tree-Wood categories were of insufficient sample size for meaningful regression analysis.

Figure 2 shows the relationship between sample size and prediction variability, presented as one-half the $95 \%$ prediction-interval width, for point-intercept frequency as determined from Monte Carlo sampling and as estimated from Equation 3. Measured and predicted variability in biomass estimates are shown in Figure 3 and are equivalent to the special doublesampling case in which the number of biomass estimates is equal to the number of point-intercept measurements.

Figure 3 also shows the relationship between sample size and mean variability in biomass estimate as a function of doublesampling scenario. In general, the most efficient doublesampling scenario for biomass was obtained when the number of biomass samples was equal to the number of strata classified within the point-intercept data and was measured for the plot representing the median point-intercept value within the stratum. All double-sampling scenarios in which one or more random biomass samples were taken per stratum exhibited variability estimates between the upper and lower data ranges shown in Figure 3 (data not shown).

Time/cost for biomass sampling was based on field time and time spent handling samples in the laboratory. Oven drying

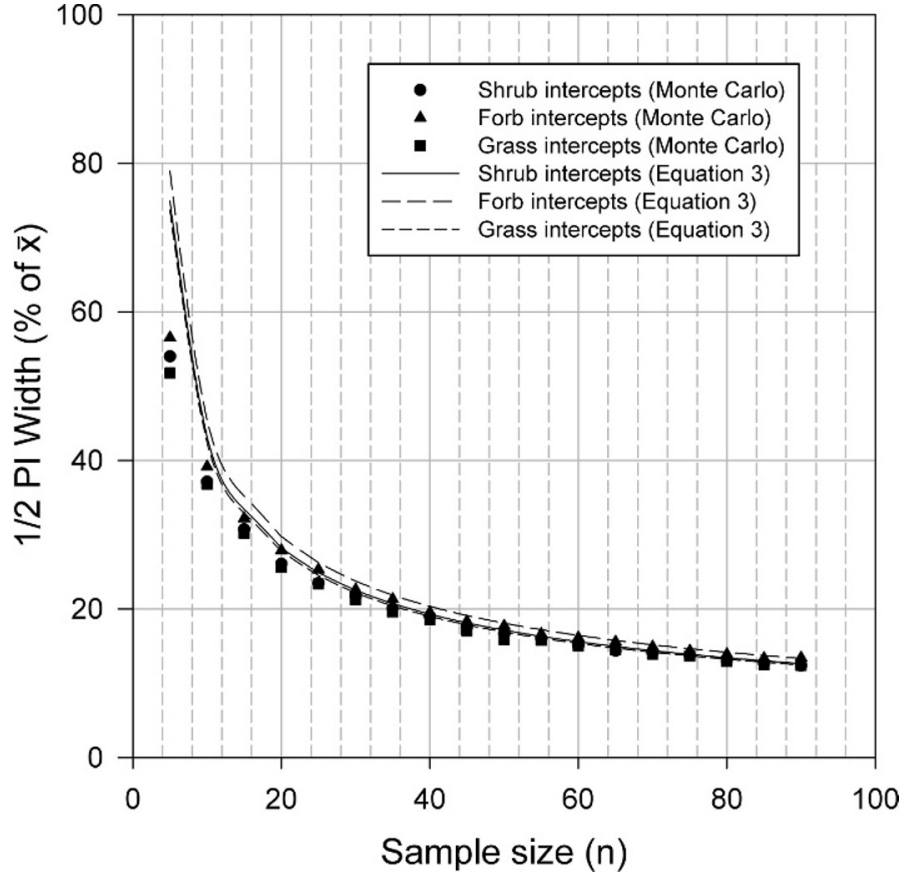

Figure 2. Relationships derived from a synthetic population of 10000 data values, between sample size and one-half of the $95 \%$ predictioninterval width for point-intercept frequency (expressed as a percentage of the mean value) as determined from Monte Carlo sampling (symbols) and as estimated from Equation 3 (lines), for the Shrub (photosynthetic material only), Forb, and Grass functional groups.

time was excluded so that the laboratory-time costs were more easily standardized and reflected personnel time only. Biomass sampling was considerably more time costly than point sampling $(P<0.0001)$, such that the biomass/point sampling cost ratio for a plot containing less than $2000 \mathrm{~g} \cdot \mathrm{m}^{-2}$ was about 3.5:1 (Figs. 4A and 4C). Field time required for biomass sampling was highly variable $(\bar{x}=42.1 \mathrm{~min}, \mathrm{SD}=42.1 \mathrm{~min})$. Mean laboratory handling time for biomass sampling was $19.6 \mathrm{~min} \cdot \operatorname{plot}^{-1} \pm 3.30 \mathrm{SD}$. Combined mean field and laboratory time for biomass sampling was $61.7 \mathrm{~min} \cdot \mathrm{plot}^{-1} \pm 42.1$ SD. Mean time-cost for point sampling was $21.8 \mathrm{~min} \cdot \mathrm{plot}^{-1}$ \pm 20.4 SD. Both biomass sampling time $(P<0.0001)$ and point sampling time $(P<0.0001)$ exhibited a linear increase with increasing total biomass on the plot (Fig. 4B). The timecost ratio (biomass sampling/point sampling), however, declined in a curvilinear fashion with increasing total biomass (Fig. 4C).

If one considers only the double-sampling schemes where 1) number of biomass samples $(m)$ equals the number of strata $(s)$, 2) the ratio of the number of point-intercept samples over strata $(i / s)$ is a whole number, and 3) biomass is only measured for the median $i$ value for each $s$, then the cost of a given doublesampling scenario, relative to the cost of sampling $m$ and $i$ for all plots, is fixed. For $s=i / 2, i / 3$, and $i / 5$, these cost savings are $39 \%$, $52 \%$, and $62 \%$ of sampling all plots, respectively, regardless of the magnitude of $i$. The mean loss of precision in biomass estimate for these same sampling ratios, however, is $18 \% \pm 4$ SD, $34 \% \pm 6 \mathrm{SD}$, and $62 \% \pm 12 \mathrm{SD}$ for values of $i$ between 10 and 90 . For all sampling scenarios in which $s<i / 5$, the relative loss of precision in the biomass estimate exceeds the cost savings. 

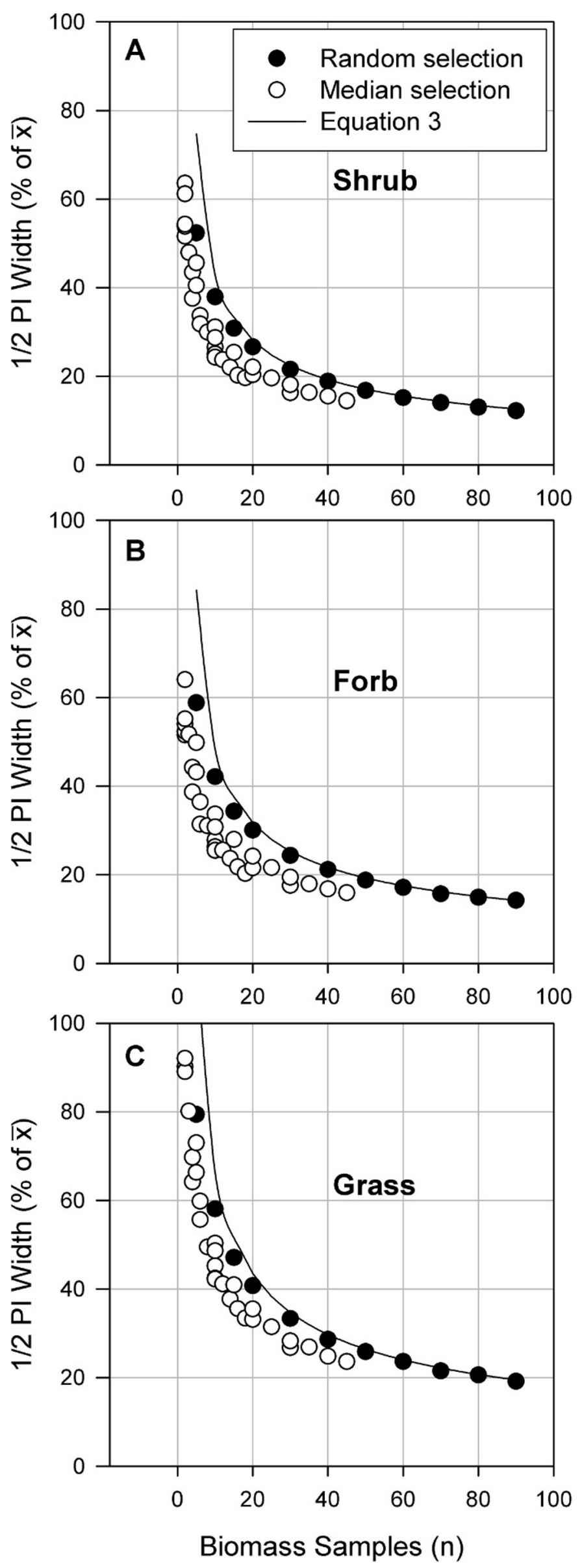

\section{DISCUSSION}

The simplest scenario for estimating sample-size requirements for biomass and cover is to randomly sample both variables and to iteratively assess the relationship between sample size and sample variability using equation 3 (Figs. 2 and 3). One would continue sampling and iteratively recalculate the sample mean and standard deviation until further reduction in sample variability was no longer cost effective. In the current study, this procedure would have shown that beyond a sample size of approximately 30 plots, the cost of additional sampling would probably not have offset the relatively small additional increase in sample precision (Figs. 2 and 3). The well-defined relationship between point-intercept frequency and biomass demonstrated in Figure 1, and the relatively higher cost of biomass sampling (Fig. 4), however, creates an opportunity to obtain the similar precision of subsequent biomass estimates with significantly fewer samples (Fig. 3). In general, optimized double-sampling scenarios were always obtained for schemes in which biomass was only measured in the plot having the median point-intercept value for each stratum. Increased precision could always be obtained by additional point sampling and from sampling from additional strata, but for our data, the most efficient sampling strategy was to measure $i /$ 2 biomass samples, which lowered the sampling cost by $39 \%$, but only increased mean sample variability by $18 \%$.

Uresk et al. (1977) demonstrated a technique for using a lessexpensive measurement parameter to stratify subsequent sampling of a more expensive variable. The potential utility of this general technique, however, requires only that the two variables be relatively well correlated. A large number of previous studies have shown good correlation between biomass and shrub-volume dimensions (Evans and Jones 1958; Medin 1960; Mason and Hutchings 1967; Lyon 1968; Bently et al. 1970; Ludwig et al. 1975; Harniss and Murray 1976; Rittenhouse and Sneva 1977; Uresk et al. 1977; Dean et al. 1981; Martin et al. 1981; Murray and Jacobson 1982; Frandsen 1983), canopy cover (Payne 1974; Anderson and Kothmann 1982; Alaback 1986), visual obstruction (Benkobi et al. 2000; Vermeire et al. 2002), digital image interception (Bennett et al. 2000), sward height (Duru et al. 2000), basal area (Ganskopp and Rose 1992), and shrub-stem basal diameter (Brown 1976; Brand and Smith 1985; Alaback 1986). All of these relationships could be used to provide a more cost-efficient estimate of biomass through double-sampling stratification. In many cases, shrub volume or some of the other low-cost parameters may not be of great interest, per se, or would not be applicable for stratifying biomass estimates for other plant functional groups.

\section{$\leftarrow$}

Figure 3. Relationships, derived from a synthetic population of 10000 data values, between sample size $(n)$ and one-half of the $95 \%$ predictioninterval width for biomass (expressed as a percentage of the mean value), for the A, Shrub (green, photosynthetic material only), B, Forb, and C, Grass functional groups, as determined by Monte Carlo sampling (5000 iterations) under scenarios where a biomass sample was selected at random (solid dots) from each stratum, the biomass sample representing the median value of each stratum was selected (open circles), and as estimated using equation 3 (solid line). 

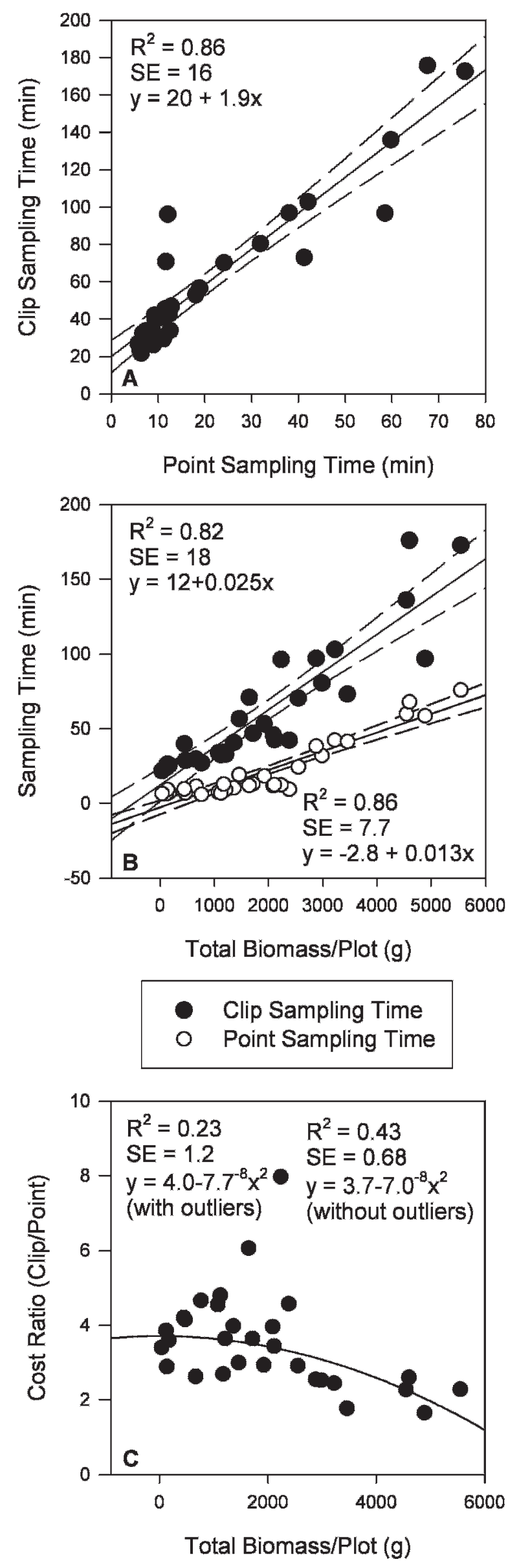

The relationship between cover and yield estimates, however, is well documented for most types of vegetation (Hughes 1962; Branson et al. 1966; Vogel and Van Dyne 1966; Poissonet et al. 1973; Ganskopp and Miller 1986; Aase 1987; Heitschmidt and Dowhower 1991), and cover or leaf area is usually of equal interest in many monitoring applications.

Resource availability frequently determines the maximum acceptable cost of sampling, and the sampling objectives are, therefore, to maximize cost efficiency rather than to achieve a given level of sampling precision. We had the advantage of retrospectively conducting sensitivity analysis on alternative sampling schemes from a relatively large sample, made larger by creation of a synthetic population. A more typical field scenario, however, would require that sample-size decisions be made in the field with little or no preliminary information about sample variability. We would recommend that the initial sample size for the less-expensive measurement be made using the traditional technique of iteratively estimating the relationship between sample size and variability from random samples using Equation 3. This approach, however, may yield slightly biased estimates. Although more logistically complicated, Cochran (1977) offers an alternative, two-step approach, which includes bias corrections.

A general rule of thumb for double-sampling biomass would be to sample from the plot with the median point-intercept value for the stratum. The maximum practical number of subsequent strata/biomass samples would be equal to $i / 2$, but sampling strategies with fewer biomass samples would not be cost effective below a value of $s=i / 5$. Effective sampling designs for other plant communities could probably be developed from one initial study, of the type described here, which could be used for additional monitoring by double-sampling within the same general plant community. Alternatively, analysis of regression variability from published studies, of the type cited here, could be used to derive cost-effective sampling scenarios for a variety of other plant communities. One potential problem with the proposed sampling design is that plots would have to be revisited for biomass sampling after analysis of the variability in pointintercept data was conducted. If this is not feasible or if the correlation of variables is significantly lower than found in this study, an RSS sampling scheme may be an appropriate alternative (Patil and Tallie 1993).

\section{MANAGEMENT IMPLICATIONS}

The acquisition of both point-intercept and biomass data are common objectives in many field-monitoring applications.

$\leftarrow$

Figure 4. Regression relationships for A, point-sampling time-costs relative to clip-sampling time-costs with $95 \%$ confidence intervals (dashed lines); B, clip-sampling and point-sampling time-cost relative to total biomass with 95\% confidence intervals (dashed lines); and C, time-cost ratio (clip-sampling/point-sampling) relative to total biomass collected from randomly located, $1-\mathrm{m}^{2}$ plots on a mountain big sagebrush-antelope bitterbrush rangeland in Reynolds Creek Experimental Watershed in southwestern Idaho. Regression statistics illustrate the fit where two outlying data points are included and excluded for the analyses. 
Given the dual monitoring objective, it is possible to design a sampling protocol that would increase the cost efficiency of biomass sampling by using strata identified within the variability of the more easily obtained point-intercept data. A general guideline for stratified double-sampling of shrub, grass, and forb species in mountain big sagebrush plant communities would be to establish minimum sample size requirements for pointintercept sampling from iterative random sampling and to measure at least one-third or one-half of the plots for biomass, if possible. General guidelines for other plant communities could be determined and confirmed from either preliminary sampling, or from analysis of previously published data describing the variability between parameters. In general, this technique could be used for any two parameters that are correlated and for which one measurement is relatively less costly to obtain. This technique can also be used to increase the efficiency of regression development in applications where biomass or another invasive measurement needs to be estimated nondestructively.

\section{ACKNOWLEDGMENTS}

The authors gratefully acknowledge the thorough review and helpful comments provided by D. Ganskopp, M. Borman, M. Sternberg, and two anonymous reviewers. This research was funded by the USDA Agricultural Research Service.

\section{LITERATURE CITED}

Aase, J. K., A. B. Franks, and R. J. Lorenz. 1987. Radiometric reflectance measurements of northern Great Plains rangeland and crested wheatgrass pastures. Journal of Range Management 40:299-302.

Ahmed, J., And C. D. Bonham. 1982. Optimum allocation in multivariate double sampling for biomass estimation. Journal of Range Management 35:777-779.

Ahmed, J., C. D. Bonham, AND W. A. Laycock. 1983. Comparison of techniques used for adjusting biomass estimates by double sampling. Journal of Range Management 36:217-221.

AlabaCK, P. B. 1986. Biomass regression equations for understory plants in coastal Alaska: effects of species and sampling design on estimate. Northwest Science 60:90-103.

Anderson, D. M., and M. M. Kothmann. 1982. A two-step sampling technique for estimating standing crop of herbaceous vegetation. Journal of Range Management 35:675-677.

Benkobi, L., D. W. Uresk, G. Schenbeck, and R. M. King. 2000. Protocol for monitoring standing crop in grasslands using visual obstruction. Journal of Range Management 53:627-633.

Bennett, L. T., T. S. Judd, And M. A. Davis. 2000. Close-range vertical photography for measuring cover changes in perennial grasslands. Journal of Range Management 53:634-641.

Bentley, J. R., D. W. Seegrist, and D. A. Blakeman. 1970. A technique for sampling low shrub vegetation by crown volume classes. Berkley, CA, USA: USDA Forest Service, Pacific Southwest Forest and Range Experiment Station. Research Note PSW-215. $11 \mathrm{p}$.

Blankenship, J. O., AND D. R. Smith. 1966. Indirect estimation of standing crop. Journal of Range Management 19:74-77.

BonHAm, C. D. 1987. Measurements for Terrestrial Vegetation. New York, NY, USA: John Wiley and Sons. $338 \mathrm{p}$.

Brand, G. J., ANd W. B. Smith. 1985. Evaluating allometric shrub biomass equations. Canadian Journal of Botany 63:64-67.

Branson, F. A., R. F. Miller, and I. S. McQueen. 1966. Contour-furrowing, pitting, and ripping on rangelands of the western United States. Journal of Range Management 19:182-190.
Breusch, T. S., and A. R. Pagan. 1979. A simple test for heteroskedasticity and random coefficient variation. Econometrica 47:1287-1294.

Brown, J. K. 1976. Estimating shrub biomass from basal stem diameters. Canadian Journal of Forest Research 6:154-158.

Cain, S. A., and G. M. de Oliveira Castro. 1971. Manual of vegetation analysis. New York, NY, USA: Hafner Publishing Company. 325 p.

Cochran, W. G. 1977. Sampling techniques. 3rd ed. New York, NY, USA: Wiley. $428 \mathrm{p}$.

Conant, S., And P. G. Risser. 1974. Canopy structure of a tall-grass prairie. Journal of Range Management 27:313-318.

Dean, S. A., J. W. Burkhardt, and R. O. Meeuwig. 1981. Estimating twig and foliage biomass of sagebrush, bitterbrush, and rabbitbrush in the Great Basin. Journal of Range Management 34:224-227.

Duru, M., H. Ducroca, and L. Bossuet. 2000. Herbage volume per animal: a tool for rotational grazing management. Journal of Range Management 53:395-402.

Evans, R. A., And M. B. Jones. 1958. Plant height times ground cover versus clipped examples for estimating forage production. Agronomy Journal 50:504-506.

Frandsen, W. H. 1983. Modeling big sagebrush as a fuel. Journal of Range Management 36:596-600.

Ganskopp, D., And R. Miller. 1986. Estimating leaf area of big sagebrush from measurement of sapwood. Journal of Range Management 39:338-340.

Ganskopp, D., AND J. RoSE. 1992. Bunchgrass basal area affects selection of plants by cattle. Journal of Range Management 45:538-541.

Glatzle, A., A. Mechel, and M. E. Vaz Lourenco. 1993. Botanical components of annual Mediterranean grasslands as determined by point-intercept and clipping methods. Journal of Range Management 46:271-274.

GreIG-Smith, P. 1983. Quantitative plant ecology. 3rd ed. Berkeley, CA, USA: University of California Press. 357 p.

Hanson, C. L. 2001. Long-term precipitation database, Reynolds Creek Experimental Watershed, Idaho, United States. Water Resources Research 37:2831-2834.

Hanson, C. L., D. Marks, and S. S. Van Vactor. 2001. Long-term climate database, Reynolds Creek Experimental Watershed, Idaho, United States. Water Resources Research 37:2839-2841.

Harniss, R. 0., and R. B. Murray. 1976. Reducing bias in dry leaf weight estimates of big sagebrush. Journal Range Management 29:430-432.

HazelL, D. B. 1965. Vegetative composition, forage production, and plant vigor as influenced by date of mowing. Journal of Range Management 18: 261-264.

Heitschmidt, R. K., And S. L. Dowhower. 1991. Herbage response following control of honey mesquite within single tree lysimeters. Journal of Range Management 44:144-149.

Hughes, E. E. 1962. Estimating herbage production using inclined point frame. Journal of Range Management 15:323-325.

Hyder, D. N., And F. A. Sneva. 1956. Herbage response to sagebrush spraying. Journal of Range Management 9:34-38.

Jonasson, S. 1988. Evaluation of the point intercept method for estimation of plant biomass. Oikos 52:101-106.

Kaur, A., G. P. Patil, A. K. Sinha, and C. Taillie. 1995. Ranked set sampling: an annotated bibliography. Environmental and Ecological Statistics 2:25-54.

LudwiG, J. A., J. F. Reynolds, And P. D. Whitson. 1975. Size-biomass relationships of several Chihuahuan desert shrubs. American Midland Naturalist 94:451-461.

LYoN, L. J. 1968. Estimating twig production of serviceberry from crown volumes. Journal of Wildlife Management 32:115-I19.

Martin, R. E., D. W. Frewing, and J. L. McClanahan. 1981. Average biomass of four northwest shrubs by size class and crown cover. Portland, OR, USA: USDA, Forest Service, Pacific Northwest Forest and Range Experiment Station. Research Note PNW-374. 6 p.

Mason, L. R., AND S. S. Hutchings. 1967. Estimating foliage yields on Utah juniper from measurements of crown diameter. Journal of Range Management 20:161-166.

Medin, D. E. 1960. Physical site factors influencing annual production of true mountain mahogany, Cercocarpus montanus. Ecology 41:454-460.

MurRay, R. B., And M. Q. Jacobson. 1982. An evaluation of dimension analysis for predicting shrub biomass. Journal of Range Management 35:451-454. 
Owens, M. K., K. L. Launchbaugh, and J. W. Holloway. 1991. Pasture characteristics affecting spatial distribution of utilization by cattle in mixed brush communities. Journal of Range Management 44:118-123.

Papanastasis, V. P. 1985. Stubble height, basal cover, and herbage production relationships in grasslands of northern Greece. Journal of Range Management 38:247-250.

Patil, G. P., and C. Talllie. 1993. Environmental sampling, observational economy and statistical inference with emphasis on ranked set sampling, encounter sampling and composite sampling. In: Bulletin of the International Statistical Institute: the ISI 49th session contributed papers; 25 August to 2 September 1993; Firenze, Italy. Voorburg, The Netherlands: ISI. p. 295-312.

Payne, G. F. 1974. Cover-weight relationships. Journal of Range Management 27:403-404

Pitt, M. D., and H. F. Heady. 1979. The effects of grazing intensity on annual vegetation. Journal of Range Management 32:109-114.

Pitt, M. D., and F. E. Schwab. 1990. Assessment of a non-destructive method for estimating browse use. Journal of Wildlife Management 54:175-179.

Poissonet, P. S., J. A. Poissonet, M. P. Godron, and G. A. Long. 1973. A comparison of sampling methods in dense herbaceous pasture. Journal of Range Management 26:65-67.

Reese, G. A., R. L. Bayn, and N. E. West. 1980. Evaluation of double-sampling estimators of subalpine herbage production. Journal of Range Management 33:300-306.

Reppert, J. N., M. J. Morris, and C. A. Graham. 1962. Estimation of herbage on California annual-type range. Journal of Range Management 15:318-323.

Rittenhouse, L. R., and F. A. Sneva. 1977. A technique for estimating big sagebrush production. Journal of Range Management 30:68-70.
SAS. 2003. NPAR1WAY procedure. In: V. Clark [ED]. SAS/STAT user's guide version 9.1. Cary, NC, USA: SAS Institute, Inc. p. 3143-3194.

Schacht, W., and J. Stubbendieck. 1985. Prescribed burning in the Loess Hills mixed prairie of southern Nebraska. Journal of Range Management 38: 47-50.

Smith, G., J. L. Holochek, and M. Cardenas. 1994. Observation: cattle diets on excellent and good condition Chihuahuan desert rangelands. Journal of Rangeland Management 47:405-409.

Stoddart, L. A., A. D. Smith, And T. W. Box. 1975. Range management. New York, NY, USA: McGraw-Hill Company. 532 p.

Tanner, G. W., J. M. Wood, R. S. Kalmbacher, and F. G. Martin. 1988. Mechanical shrub control on flatwoods range in south Florida. Journal of Range Management 41:245-248.

Tsutsumi, M., S. Itano, and M. Shiyomi. 2007. Number of samples required for estimating herbaceous biomass. Rangeland Ecology and Management 60:447-452.

Uresk, D. W., R. O. Gilbert, and W. H. Rickard. 1977. Sampling big sagebrush for phytomass. Journal of Range Management 30:311-314.

Vermeire, L. T., A. C. Ganguli, and R. L. Gillen. 2002. A robust model for estimating standing crops across vegetation types. Journal of Range Management 55:494-497.

VogeL, W. G., And G. M. VAn Dyne. 1966. Vegetation responses to grazing management on a foothill sheep range. Journal of Range Management 19:80-85.

Wight, J. R., E. L. NefF, AND R. J. Solseth. 1978. Vegetation response to contour furrowing. Journal of Range Management 31:97-101.

WILM, H. G. 1944. Estimating forage yield by the double-sampling method. Journal of the American Society of Agronomy 34:194-203. 